\title{
Bandar Udara dengan Pendekatan Wayfinding di Panimbang Pandeglang Banten
}

\author{
Anggraeni Budi Kusriarti, Hadi Setyawan, Edi Pramono Singgih \\ Program Studi Arsitektur \\ Fakultas Teknik \\ Universitas Sebelas Maret Surakarta \\ Email : anggraeniabk@gmail.com
}

\begin{abstract}
The designing of airport in Panimbang, Pandeglang, Banten is effected by Government plans to build infrastructure for Special Economic Region Tanjung Lesung which is located in Pandeglang Regency. Infrastructure in the form of airport to accomodate the tourists come to the tourism area in Banten especially to Special Economic Area of Tanjung Lesung. The problems that arise in the designing of the airport is how to form building design that is able to accomodate the air transport activities and meet the space requirements for the user in the form of Airport buildings by applying the concept of wayfinding at the building. The purpose of design is to meet the demands of Airport needs, functions, and user character by creating a smooth and easy-to-understand circulation and also provide convenience for the user. Wayfinding concept that is applied is the concept of the district, street concept, connector, and landmarks on the interior and exterior. The concept of planning and designing the form of the design of airport in Panimbang, Pandeglang, Banten, which served as an infrastructure for Special Economic Region Tanjung Lesung in the form of accomodation for air transportation activities that meet the needs of users in which elements of its architecture is able to create a smooth circulation by projecting the surrounding environment and the flow of events.

Keywords: Architecture, Airports, Infrastructure, Circulation, Wayfinding
\end{abstract}

\section{PENDAHULUAN}

Rencana pembangunan Kawasan Ekonomi Khusus Tanjung Lesung oleh pemerintah setempat dilakukan untuk meningkatkan jumlah kedatangan wisatawan ke Propinsi Banten khususnya Kabupaten Pandeglang. Rencana pembangunan tersebut diikuti oleh rencana pembangunan infrastruktur Kawasan Ekonomi Khusus Tanjung Lesung berupa bandar udara. Infrastruktur yang mampu memenuhi kebutuhan pengguna dalam moda transportasi. Bandar udara yang direncanakan berada dengan Kawasan Ekonomi Khusus Tanjung Lesung.

Bandar udara adalah kawasan di daratan dengan batas tertentu yang berfungsi sebagai wadah kegiatan transportasi udara berupa pesawat udara. Bandar udara merupakan sebuah fasilitas transportasi umum dengan jadwal yang telah di tentukan, maka diperlukan efisiensi waktu yang baik dalam alur kegiatannya. Efisiensi waktu dapat dicapai dengan sirkulasi yang lancar, jelas, dan mudah. Sirkulasi dipengaruhi oleh beberapa faktor, yaitu dimensi ruang serta kapasitas ruang yang sesuai dengan jumlah dan kebutuhan pengguna, pengelompokkan ruang guna membantu pengguna untuk memproyeksikan urutan tindakan, pola tata ruang yang mampu menciptakan kelancaran serta kenyamanan, dan petunjuk untuk membantu pengguna mengintegrasikan diri dengan lingkungan.

Tujuan perancangan adalah dapat mewujudkan visi misi pemerintah untuk membangun infrastruktur berupa bandar udara yang mampu memenuhi tuntutan kebutuhan, fungsi, dan karakter pengguna dengan menciptakan sirkulasi yang lancar dan mudah di pahami. Dalam perancangan bandar udara yang terpenting adalah aspek sirkulasi, sirkulasi yang lancar dengan kapasitas sesuai pengguna, pengelompokkan ruang sesuai fungsi, pola tata ruang yang efisien, dan petunjuk yang mudah dimengerti.

\section{METODE}

Strategi dalam wayfinding merupakan garis dasar dalam desain wayfinding serta sistem tanda pada suatu titik. Strategi dalam wayfinding dapat membantu perancang dalam menentukan alur seluruh aspek baik 
eksterior maupun interior dalam perancangan seperti jaringan sistem transportasi, bangunan publik atau komersial, dan lingkungan hingga skala kota. (Gibson, 2009)

Berikut empat stategi dalam penerapan wayfinding dalam desain menurut buku Wayfinding-Handbook karya Gibson (2009) :

1. Konsep distrik, yang menandakan bahwa setiap wilayah baik itu perkotaan maupun rumah tinggal sekalipun terbagi dalam beberapa distrik-distrik tertentu atau dalam arsitektural disebut pengelompokkan ruang. Konsep distrik ini dapat berdasarkan fungsi dan pengguna, sehingga memudahkan untuk di ingat.

2. Street concept. Konsep alur sirkulasi seperti penerapan sistem jalan pada wilayah perkotaan, pada wilayah lingkungan disebut jalan setapak dan disebut alur sirkulasi atau pola sirkulasi jika konsep diterapkan pada suatu bangunan. Sama halnya dengan sistem jalanan, konsep ini juga menerapkan jalan utama/protokol dan jalan kecil.

1. User circulation

Pola sirkulasi ini memudahkan user bergerak bebas sesuai dengan fungsi masing-masing. Antara pengelola dan pengguna lain tidak di beri jalur sirkulasi yang sama hingga akses masuk ke dalam bangunan (user oriented).

2. Pedestrian and vehicular circulation

Pola sirkulasi yang lebih mengatur pergerakan kendaraan dan pejalan kaki khususnya di area yang luas seperti kampus atau universitas hingga kota sekali pun.

3. Connector. Konsep penghubung yang menghubungkan semua tujuan dengan suatu lokasi tertentu. Connector merupakan penerapan yang lebih sederhana dari path atau sirkulasi. Connector dapat berupa lorong, jembatan, dan ruang.

4. Landmark. Titik strategis atau nodes utama yang secara langsung diingat oleh pengguna. Landmark tidak harus bentuk dengan dimensi yang besar, landmark dapat berupa lift yang berada di tengah atau suatu titik utama yang dituju. Landmark juga dapat berbentuk vantage point atau titik kumpul bersama.

\section{ANALISIS}

Pada sub bab ini akan membahas tentang analisis perencanaan dan perancangan bandar udara berupa peruangan, tapak, pencapaian, kebisingan, pengelompokkan ruang, dan struktur.

\subsection{Analisis Peruangan}

Tabel 1. Kebutuhan Ruang

\begin{tabular}{|l|l|}
\hline Pengguna & Kebutuhan Ruang \\
\hline Penumpang & $\begin{array}{l}\text { Curb, hall, hall check in, } \\
\text { baggage claim area, } \\
\text { lavatory, ruang komersial, } \\
\text { musholla, ruang tunggu, } \\
\text { executif lounge, parkiran }\end{array}$ \\
\hline $\begin{array}{l}\text { Pengantar / } \\
\text { penjemput }\end{array}$ & $\begin{array}{l}\text { Curb, hall, area komersial, } \\
\text { lavatory, musholla, } \\
\text { parkiran }\end{array}$ \\
\hline $\begin{array}{l}\text { Maskapai } \\
\text { penerbangan }\end{array}$ & $\begin{array}{l}\text { Hall, ruang karyawan, } \\
\text { counter check in, } \\
\text { musholla, toilet, gudang, } \\
\text { parkiran }\end{array}$ \\
\hline $\begin{array}{l}\text { Pengelola } \\
\text { terminal }\end{array}$ & $\begin{array}{l}\text { Hall, } \text { musholla, ruang } \\
\text { kepala bandara, toilet, } \\
\text { parkiran }\end{array}$ \\
\hline $\begin{array}{l}\text { Pengelola } \\
\text { komersial }\end{array}$ & $\begin{array}{l}\text { Hall, area komersial, } \\
\text { lavatory, musholla, ruang } \\
\text { tunggu, parkiran }\end{array}$ \\
\hline
\end{tabular}

Pada Tabel 1. terlihat kebutuhan ruang untuk memenuhi kebutuhan wadah kegiatan di bandar udara.

\subsection{Analisis Tapak}

Menganalisis tapak yang telah di tentukan guna mengetahui kelayakan tapak digunakan sebagai bandar udara.

\subsubsection{Tujuan}

Potensi tapak

\subsubsection{Dasar pertimbangan}

1. Suhu

2. Kecepatan angin

3. Kemiringan

4. Kualitas tanah

5. Ketinggian

\subsubsection{Proses analisis}

Tapak memiliki suhu rata-rata $34,7^{\circ} \mathrm{C}$ dengan kecepatan angin 6 knot dengan ketinggian tanah 503-509 $\mathrm{m}$ dan kemiringan 10-20\% yang jauh dari pemukiman sekitarnya sehingga layak menjadi tapak bandar udara.

\subsection{Analisis Pencapaian}

Pencapaian ke dalam bangunan harus mudah diakses, mudah dilihat, dan memiliki 
sirkulasi yang aman akan menstimulus orang untuk masuk dalam area bangunan.

\subsubsection{Tujuan \\ Main entrance}

\subsubsection{Dasar pertimbangan}

Kemudahan akses, arus kendaraan, dan potensi jalan.

\subsubsection{Proses analisis}

Main Entrance (ME)

Letak main entrance terdapat satu sesuai dengan bentuk tapak terhadap jalan yang memudahkan pengguna untuk mencapai objek rancang (lihat Gambar 1).

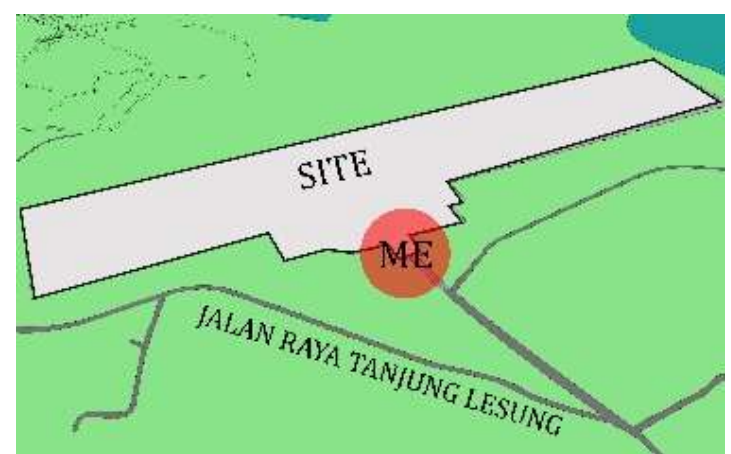

Gambar 1. Pencapaian pada Tapak

\subsection{Analisis Pengelompokkan Ruang}

Pengelompokkan ruang berdasar kegiatan, pengguna, dan fungsi diharapkan mampu menciptakan sirkulasi yang lancar dan mudah dipahami oleh pengguna.

\subsubsection{Tujuan}

Kelompok ruang।

\subsubsection{Dasar pertimbangan}

1. Kegiatan

2. Kenyamanan

3. Pengguna

4. Fungsi

\subsubsection{Proses analisis}

Pengelompokkan ruang secara horizontal didasarkan pada sifat kegiatan, yaitu :

1. Zona publik, ruang-ruang yang bersifat umum ditempatkan pada zona yang mudah dicapai pengunjung dari pintu masuk.

2. Zona semi publik, ruang-ruang yang membutuhkan privasi lebih sedikit.

3. Zona privat, ruang-ruang yang membutuhkan privasi atau ketenangan yang lebih.

4. Zona servis, ruang-ruang servis di letakkan jauh dari zona yang dapat dijangkau oleh para pengunjung, namun tetap mempertimbangkan kemudahan pencapaian bagi pengelolanya

kemudahan pencapaian bagi pengelolanya.

Pengelompokkan ruang secara vertikal didasarkan pada tingkat kebisingan dari banyaknya kegiatan, yaitu :

a. Zona bawah, merupakan zona yang memiliki tingkat kebisingan tertinggi karena adanya kegiatan yang melibatkan para pengunjung.

b. Zona transisi, merupakan zona peralihan antara zona bawah dan zona tenang.

c. Zona atas, zona paling atas dan merupakan zona tenang karena membutuhkan banyak privasi dan ketenangan yang tinggi.

Pengelompokkan ruang secara horizontal dan vertikal (lihat Gambar 2).

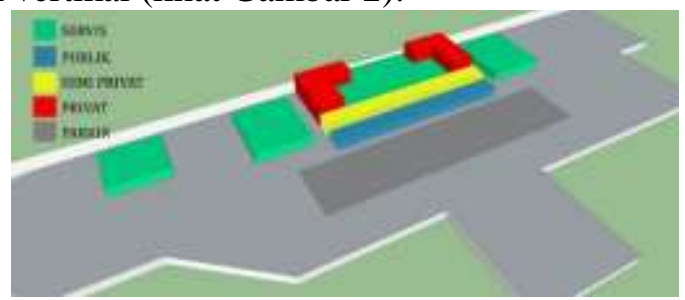

Gambar 2. Analisis Pengelompokkan Ruang

\subsection{Analisis Arsitektural Bangunan}

\subsubsection{Gubahan massa bangunan}

Gubahan massa pada objek rancang berawal dari bentuk tapak memanjang mengikuti bentuk dari runway. Bentuk awal persegi panjang yang mengalami pengurangan. Kemudian diberikan sentuhan yang menganalogikan bentuk ombak pada atap. Bandar udara yang akan dirancang merupakan infrastruktur Kawasan Ekonomi Khusus Tanjung Lesung yang merupakan sebuah tempat pariwisata berupa pantai dan fasilitas yang berada di dalamnya. Bentuk atap yang menganalogikan sebuah ombak dapat menjadi icon pariwisata yang akan diingat oleh pengguna dan wisatawan (lihat Gambar 3). 


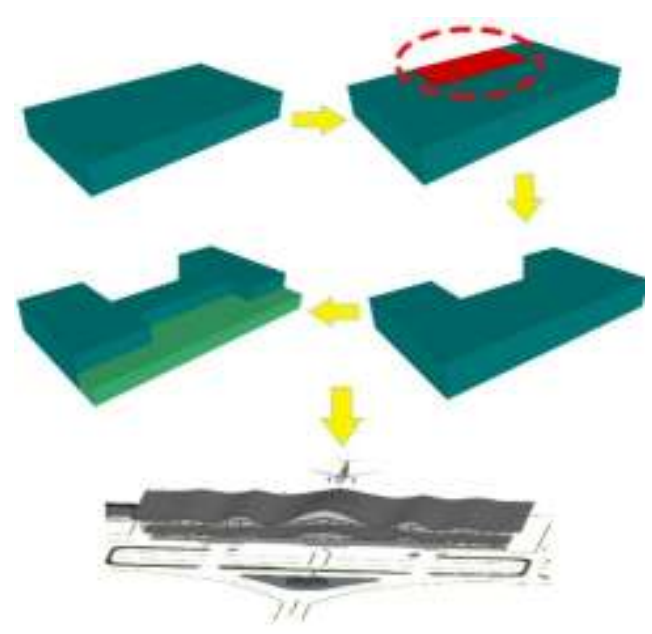

Gambar 3. Gubahan Massa Bangunan

\subsubsection{Analisis interior}

Interior adalah sesuatu penggambaran dari konsep bangunan yang dirasakan dan bersentuhan langsung dengan pengguna bangunan. Pemilihan warna dan jenis materialnya dipilih menyesuaikan dengan konsep dan fungsi bangunan.

Objek rancang akan mengusung konsep wayfinding pada bagian interior bangunan. Konsep wayfinding yang di angkat pada bangunan ini adalah konsep distrik, street concept, connector, dan landmark.

1. Konsep distrik merupakan pembagian wilayah menjadi beberapa distrik berdasarkan fungsi dan dan pengguna yang dapat dikatakan juga sebagai pengelompokkan ruang sehingga dapat memudahkan untuk di ingat oleh pengguna. Pembagian wilayah atau zona dibagi menjadi empat yaitu zona publik, zona semi publik, zona privat, dan zona servis (lihat Gambar 4).

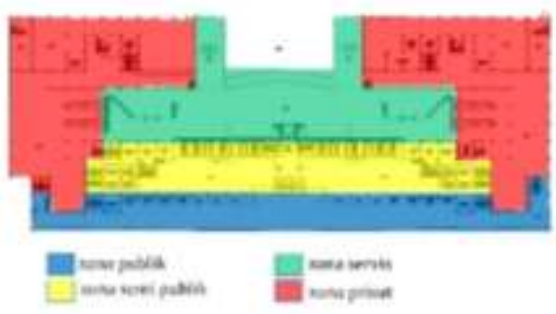

Gambar 4. Pembagian Zona

2. Street concept atau konsep sirkulasi memudahkan pengguna untuk bergerak sesuai dengan fungsi dan kebutuhan masing-masing pengguna. Konsep sirkulasi yang diterapkan pada interior ruang check-in. Penggunaan perbedaan warna di lantai dimaksudkan agar pengguna dapat mengetahui posisi pada saat mengantri untuk melakukan check-in sehingga tidak mengganggu aktivitas pengguna lain yang akan meninggalkan meja check-in (lihat Gambar 5).

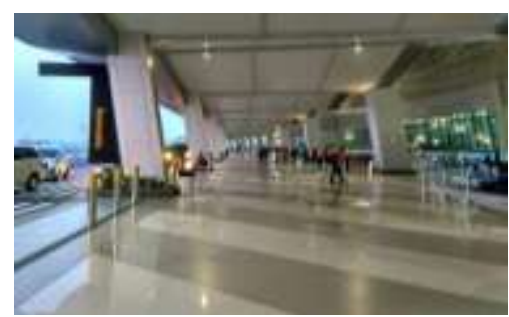

Gambar 5. Perbedaan Warna pada Lantai (http://www.roosvansia.com/)

3. Connector atau penghubung bertujuan menghubungkan semua tujuan pada suatu lokasi tertentu, berupa ruang titik kumpul maupun lorong. Ruang tunggu keberangkatan menjadi salah satu contoh ruang titik kumpul (lihat Gambar 6).

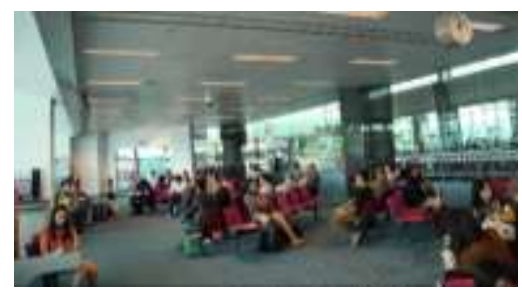

Gambar 6. Ruang Tunggu (https://backpackstory.me)

4. Landmark merupakan titik strategis yang akan memudahkan pengguna untuk mengingat suatu lokasi. Landmark pada bandar udara berupa monumen pesawat terbang dan bentuk atap yang menganalogikan ombak (lihat Gambar 7 dan 8).

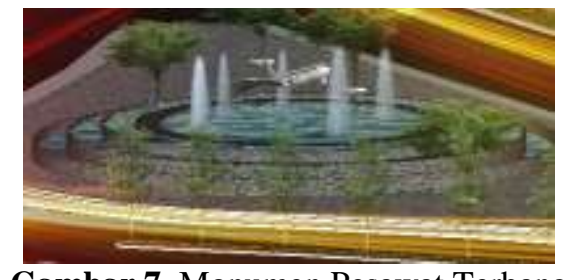

Gambar 7. Monumen Pesawat Terbang

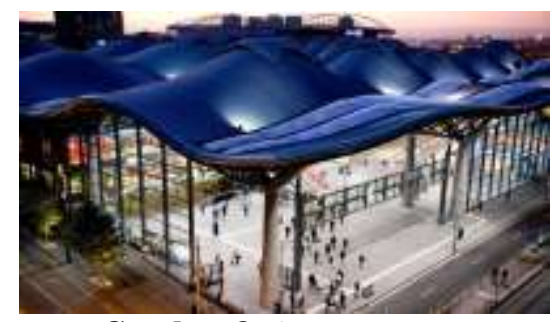

Gambar 8. Atap Bangunan (http://tekcomjar.blogspot.co.id/) 


\subsection{Analisis Struktur}

Mengacu pada hasil analisis gubahan massa dan lainnya, bandar udara memiliki dua lantai.

\subsubsection{Dasar Pertimbangan}

1. Kemampuan mendukung beban yang disesuaikan dengan pertimbangan akan keamanan, daya dukung tanah, dan sebagainya.

2. Sistem yang dipilih harus dapat mendukung dengan proses kegiatan yang berlangsung.

3. Faktor estetika dan penampilan visual yang diharapkan.

4. Kuat dengan gaya getaran horizontal yang berasal dari lalu lintas pesawat di landasan pacu.

5. Kuat menahan gaya tekan vertikal pada saat pesawat mendarat dan lepas landas.

\subsubsection{Proses Analisis}

Sistem struktur pada bangunan yang utama terdiri atas tiga bagian yaitu pondasi, rangka bangunan, dan atap. Pada dasarnya, sistem struktur dapat dibedakan menjadi tiga, yaitu:

\subsubsection{Sub structure}

Pemilihan pondasi didasarkan pada beberapa hal berikut :

1. Berat bangunan yang harus dipikul pondasi berikut beban-beban hidup, beban mati dan beban-beban lainnya serta beban-beban yang diakibatkan gaya-gaya eksternal.

2. Jenis tanah dan daya dukung tanah.

3. Perencanaan bangunan bandara yang memiliki dua lantai.

Bandar udara di Panimbang merupakan bangunan dengan kondisi tanah yang datar maka sistem pondasi dan jenis pondasi yang digunakan adalah pondasi bored pile. Pemilihan jenis pondasi ini didasari oleh kondisi tanah, fungsional bangunan, dan rencana atap yang akan menggunakan struktur bentang lebar sehingga dimaksudkan pondasi ini dapat menahan beban yang diciptakan dari massa bentang atap (lihat Gambar 9).

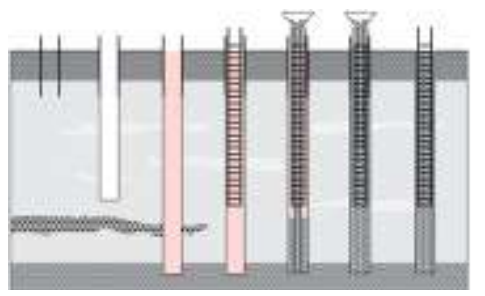

Gambar 9. Pondasi Bored Pile (www.google.com)

\subsubsection{Super structure}

Bandar udara di Panimbang menggunakan struktur hollow structural section atau kolom baja berongga. Kolom ini akan didesain berbentuk silinder, diatasnya yang akan menjadi titik pertemuan struktur shell atap bentang lebar.

Menggunakan bentukan silinder dimaksudkan agar dapat menahan gaya horizontal saat bekerja pada bagian bawah dari hyper shell dan berfungsi sebagai beam cantilever dari lantai bawahnya (lihat Gambar 10).

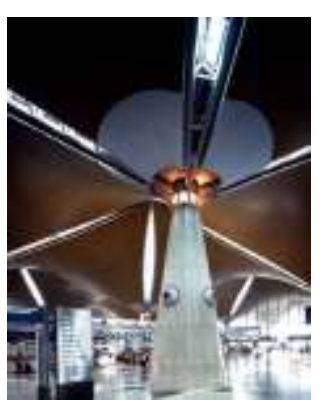

Gambar 10. Hollow Structural Section (www.google.com)

\subsubsection{Upper structure}

Untuk struktur atap pada bandar menggunakan struktur rangka ruang atau space frame. Pemilihan struktur bentang lebar ini mengingat banyak aktifitas lalu lalang yang akan terjadi di dalam terminal (lihat Gambar 11).

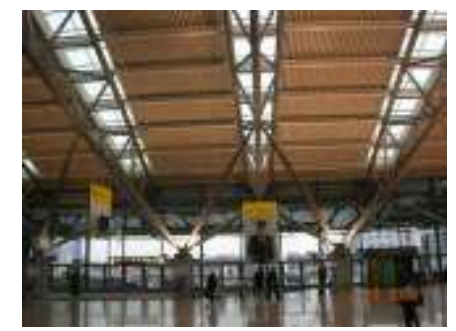

Gambar 11. Struktur Space Frame (www.google.com)

\section{KESIMPULAN}

Konsep rancangan bandar udara mengacu pada konsep wayfinding. Konsep wayfinding yang diterapkan pada bangunan bandar udara berupa konsep distrik, street concept, connector, dan landmark. Konsep distrik diterapkan berupa pembagian zona yang sesuai dengan fungsi sehingga mudah di ingat oleh pengguna. Pembagian zona dibagi menjadi empat yaitu zona publik, zona semi 
publik, zona privat, dan zona servis. Street concept yang diterapkan berupa sirkulasi untuk memudahkan pengguna untuk bergerak sesuai dengan fungsi dan kebutuhan. Konsep sirkulasi diterapkan pada penggunaan perbedaan warna pada lantai yang sesuai dengan kebutuhan gerak pengguna. Connector atau penghubung berupa titik kumpul yang menjadi tujuan pada suatu lokasi seperti ruang tunggu keberangkatan, ruang pengambilan bagasi, dan ruang checkin. Landmark merupakan titik strategis yang dapat mempermudah pengguna untuk mengingat suatu lokasi. Landmark pada bandar udara berupa monument pesawat terbang dan bentuk atap yang menganalogikan ombak (lihat Gambar 1216).

Dari hasil analisa serta hasil korelasi dari beberapa data di atas, maka diperoleh hasil berupa rancangan Bandar Udara di Panimbang, Pandeglang, Banten sebagai berikut.

Nama Bangunan : Bandar Udara

Lokasi

: Desa Mekarsari,

Kecamatan Panimbang, Kabupaten

Pandeglang, Propinsi Banten

$\begin{array}{ll}\text { Luas Lahan } & : 2.747 .320 \mathrm{~m}^{2} \\ \text { Luas Bangunan } & : 29.150 \mathrm{~m}^{2} \\ \text { Kegiatan } & : \text { Transportasi udara }\end{array}$

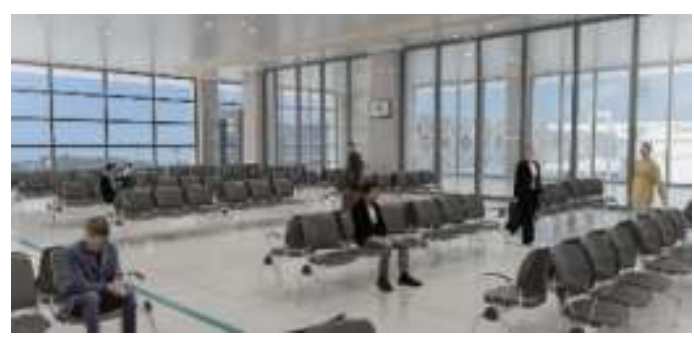

Gambar 12. Ruang Tunggu Keberangkatan sebagai Titik Kumpul

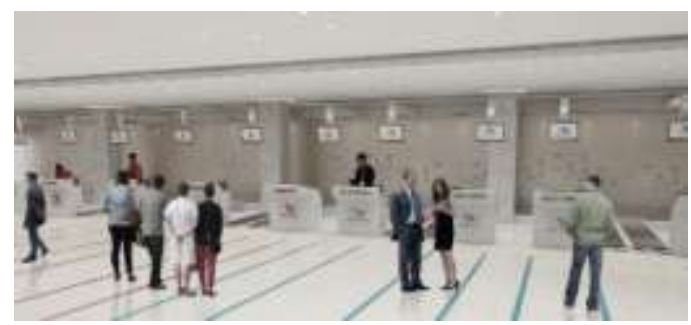

Gambar 13. Perbedaan Warna Lantai untuk Jalur Sirkulasi Check-in

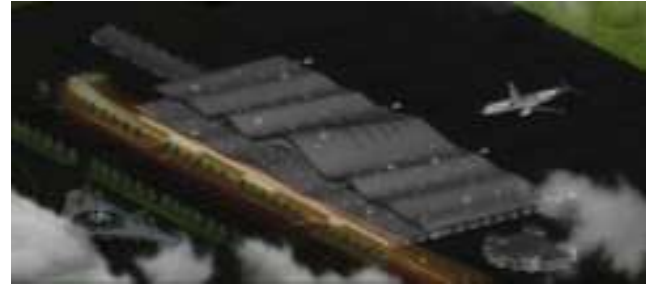

Gambar 14. Atap Menyerupai Ombak

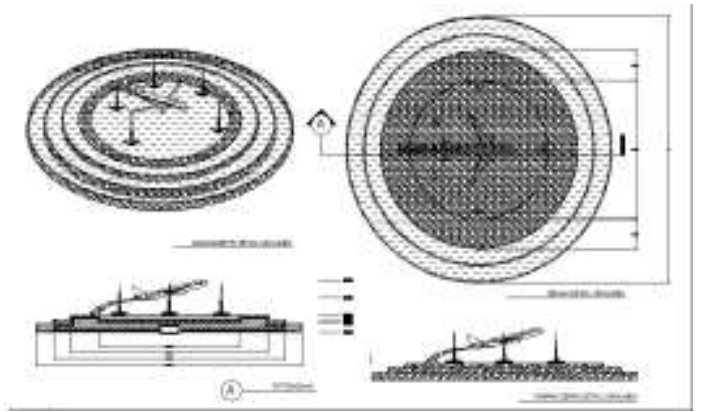

Gambar 15. Detail Monumen Pesawat

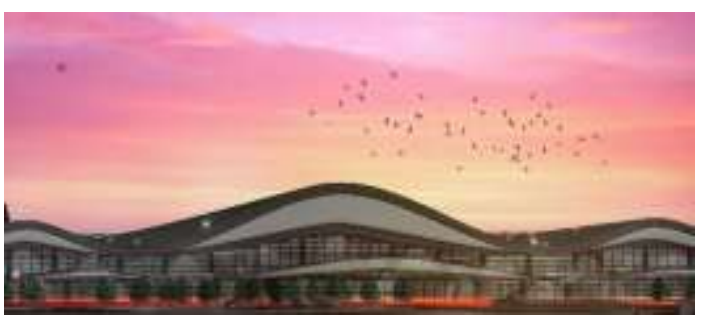

Gambar 16. Perspektif Eksterior

\section{REFERENSI}

Gibson, David. 2009. Wayfinding Handbook: Information Design for Public Places. New York, USA: Princeton Architectural Press.

www.backpackstory.me diakses pada 8 September 2016 pukul 13.15 www.google.com diakses pada 26 Agustus 2016 pukul 15.34

www.roosvansia.com diakses pada 8

September 2016 pukul 12.13

www.tekcomjar.blogspot.co.id diakses pada

8 September 2016 pukul 13.40 